\title{
PERCEIVED EFFECT OF MICROFINANCE SERVICES IN SAN JOSE, OCCIDENTAL MINDORO
}

\author{
Rizzi Angelica T. Dagos \\ College of Agriculture, Occidental Mindoro State College, San Jose, Occidental Mindoro, Philippines. \\ E-mail: radagos926@gmail.com
}

Citation: Dagos, R.A.T. 2021. Perceived Effect of Microfinance Services in San Jose, Occidental Mindoro. J. Asian Rur. Stud. 5(2): 90-97

\begin{abstract}
This study aimed to determine the role of microfinance institutions (MFIs) in alleviating poverty among households of San Jose, Occidental Mindoro. Particularly, this study aimed to: (1) characterize microfinance household clients in San Jose, Occidental Mindoro, in terms of: sociodemographic, economic and communication; (2) determine the driving forces of clients to avail microfinance services; (3) identify the household-clients' frequently availed/accessed/paid microfinance services; and (4) determine the household clients' perceived effect of microfinance services in terms of: economic, social and personal. A total of 200 randomly selected household MFI clients, both from rural and urban barangays of San Jose, Occidental Mindoro were interviewed for this study. Descriptive statistics such as mean, weighted mean, frequency and percentage distribution were used in analysing and presenting the data. The results of the study revealed that most of the respondents are female, married and literate. They have other sources of income. Among the most common driving forces of household clients in availing microfinance services are financial security, health-related concerns and education. The frequently availed services of household clients are savings, insurance and loans and their most common microfinance service provider is the Center for Agriculture and Rural Development Incorporated (CARD Bank). The household clients experienced reduced poverty and increased acquisition of assets as economic effect of microfinance services, while they had improved lifestyle and improved relationships with other people as social effects and increased self-confidence and fulfillment as personal effects of microfinance services.
\end{abstract}

Keywords: Poverty; Driving Forces; Financial Sustainability

\section{Introduction}

Poverty remains to be a crucial problem in the Philippines. Family Income and Expenditure Survey (FIES) conducted by Philippine Statistics Authority revealed that Philippine's poverty rate declined from $25.2 \%$ in 2012 to $21.6 \%$ in 2015 (Suansing, 2017). In general, $12.1 \%$ lived in extreme poverty, classified as those people whose income is not enough to buy three meals per day. Data further revealed farmers, fishermen, children belonging to families with income below the official poverty threshold, self-employed and unpaid family workers and women belonging to poor families have higher poverty rates than the general population.

Microfinance is observed to play a vital role in providing the poor, such as small farmers, fishermen and micro-entrepreneurs with accessible credit and helping them improve their lives by encouraging them to engage in entrepreneurial activity (Habaradas \& Umali, 2013). Based on the study of Valdemar, Encinas and Imperio (2007), microfinance proved itself to be an effective tool to bring people out of poverty. According to World Bank (2000) as cited by Hamada (2010), microfinance is regarded as an effective tool for poverty reduction. The World Bank has proposed a set of strategies for attacking poverty: promoting opportunity, facilitating empowerment, and 
enhancing security. Furthermore, the Bangko Sentral ng Pilipinas (BSP) considers "microfinance as a means of developing an inclusive financial system that provides for the evolving needs of a diverse public" (Philippine Development Plan, 2011-2016). According to Roman (2004), "microfinance is the provision of broad range of financial services including loans, savings, insurance, remittances and transfers to low-income households and their microenterprises."

Despite the positive support of Official Development Assistance (ODA) and other foreign aid extended for microfinance program in the Philippines, microfinance services are delivered only to one third of the total poor households. Developing the industry and filling this gap is one of the major upcoming challenges of microfinance industry in the country. The microfinance institutions (MFIs) continue to face challenges that could affect their ability to reach more poor people even as they strive to achieve financial sustainability (Habaradas \& Umali, 2013). The huge number of Filipinos and Filipino families living below the poverty threshold comprise the market for microfinance services. Aside from this, those living slightly above poverty threshold, who do not yet have access to the formal financial system in the country, also comprise the potential market for microfinance products and services (Geron, 2010).

According to the study of Asian Development Bank (2007), the Philippine microcredit program had a significant impact on the number of microenterprises and the number of persons employed in them, reflecting that the program was designed to cater the entrepreneurial poor. The impact of the availability of program loans on per capita is shown to be positive and mild significant. It was also found out that the impact is regressive-negative on poorer household and positive only on the richest quartile (Kondo, Orbeta, Dincong, and Infantado, 2008). Study conducted by Coke (2002) as cited by Valdemar, Encinas and Imperio (2007) found that microfinance services have positive impacts but was not sustained on a long-term basis.

The studies showed that the microfinance is proven to be an effective tool in alleviating poverty has significant and regressive - negative impact on the lives of households' clients. Hence, this study was undertaken to determine the perceived effect of microfinance services among the householdclients in San Jose, Occidental Mindoro.

This research study aimed to determine the role of microfinance institutions in improving the quality of life of households in San Jose, Occidental Mindoro. Particularly, this study aimed to: (1) characterize microfinance household clients in San Jose, Occidental Mindoro, in terms of: sociodemographic, economic and communication; (2) determine the driving forces of clients to avail microfinance services; (3) identify the household-clients' frequently availed microfinance services; and, (4) determine the household clients' perceived effect of microfinance services, in terms of economic, social and personal aspects.

\section{Materials and Methods}

This study employed descriptive research design in assessing the household clients' perceived effect of microfinance services in San Jose, Occidental Mindoro. San Jose was the most populous municipality among the 11 municipalities comprising the province of Occidental Mindoro. The municipality of San Jose has a population size making up $29.0 \%$ of the total provincial population. Occidental Mindoro is a driving paradise with so much to offer divers out to discover several unexplored shoals and atolls. Occidental Mindoro is endowed with marine beauty from its virgin from forests, beautiful white sand beaches, islands and islets rich in marine life, coral gardens, mysterious caves, and cascading waterfalls (Department of Tourism - Philippines, 2009). The total population by Municipality of San Jose, Occidental Mindoro is 143,430 people based on the 2015 Census of Population and Housing $(\mathrm{CPH})$. The Province of Occidental Mindoro posted a total population of 143,430 persons as of August 1, 2015. In this study, household clients of microfinance institutions were interviewed to serve as respondents of this study. Respondents were randomly chosen from top five most populous urban and rural barangays in San Jose. A total of 200 respondents were interviewed, 20 respondents for each barangay. Self-constructed questionnaire was used in gathering the required data for this study. It consisted of three parts: first is the profile of microfinance clients, second is the perceived effect, third is the problems encountered of clients. Prior to interview, 
researchers provided a request letter for the respective chairpersons of identified urban and rural barangays. After approval, request letter to conduct interview was also handed to the respondents, prior to the start of interview. Descriptive statistics such as mean, frequency and \%age distribution were used in analyzing and presenting the data gathered.

\section{Results and Discussion}

\subsection{Characteristics of microfinance household-clients}

\subsubsection{Socio-demographic characteristics}

Table 1 shows the socio-demographic characteristics of microfinance household clients. It shows that $88 \%$ are female, while $12 \%$ are male. It also shows that $80.5 \%$ of household clients are married, while $2.5 \%$ are separated. In terms educational attainment, more than half of the respondents are high school graduate, highest is high school graduate $(28 \%)$, followed by high school undergraduate $(21.5 \%)$, college graduate $(16 \%)$, elementary graduate $(15 \%)$ and the least is $0.5 \%$ who had no formal schooling. The findings supported the study conducted by Kondo, Orbeta, Dingcong, and Infantado (2008) which revealed that below $1 \%$ of microfinance clients have no eductaion or formal schooling. Some $(31 \%)$ have elementary education and secondary education $(46 \%)$. The remaining $23 \%$ have tertiary education. This implies that majority of the clients are male and has the ability to basic reading and writing as revealed by their educational attainment. This also implies that the clients possess decision-making skills with respect to managing their finances.

On the average, clients are 42.5 years old which means that household clients are in their 40 's. The mean household size of microfinance clients is 5.1 or 5 , which means that microfinance clients have approximately five household members on the average. By United Nation's Department of Economic and Social Affairs Population Division (2017) definition, this is a large household size.

Table 1. Socio-demographic Characteristics of Microfinance Household-clients

\begin{tabular}{llcc}
\hline & Socio-demographic profile & Frequency & Percentage (\%) \\
\hline \multirow{2}{*}{ Sex } & Male & 24 & 12.0 \\
& Female & 176 & 88.0 \\
Civil status & Single & 27 & 13.5 \\
& Married & 161 & 80.5 \\
& Separated & 5 & 2.5 \\
& Widow/Widower & 7 & 3.5 \\
& No formal schooling & 1 & 0.5 \\
& Elementary undergraduate & 17 & 8.5 \\
Educational attainment & Elementary graduate & 30 & 15.0 \\
& High school undergraduate & 43 & 21.5 \\
& High school graduate & 56 & 28.0 \\
Age & College undergraduate & 21 & 10.5 \\
& College graduate & 32 & 16.0 \\
Household Size & Mean = 42.5 & & \\
& SD $=12.1$ & & \\
\hline & Mean $=5.1$ & & \\
\hline
\end{tabular}

\subsubsection{Economic characteristics}

Table 2 shows the estimated monthly income, occupation and other sources of income of microfinance household clients. This revealed that among the household clients, $6 \%$ has a monthly income of $\mathrm{PhP} 20,000$ and above, while 55\% of the respondents has a monthly income of $\mathrm{PhP} 3,001$ P10,000. Household's income are from both client and spouse which is pooled together to meet the expenses of the households. In terms of occupation, most of them are housewives that have other sources of income from sari-sari store, farming, fishing and salary of relatives to meet their 
obligations. Some $(21.5 \%)$ of the respondents are employees, businessmen, professional, while $13 \%$ of them are vendor. Majority (64\%) of the household clients have other income sources such as buying and selling, doing agriculture-related activities, and managing small businesses. This also contributes to their pooled income for family's expenses.

Table 2. Economic Profile of Microfinance Household-clients

\begin{tabular}{llcc}
\hline & Economic profile & Frequency & Percentage (\%) \\
\hline Estimated monthly & 3,000 and below & 32 & 16.0 \\
income & $3001-10,000$ & 110 & 55.0 \\
& $10,001-20,000$ & 46 & 23.0 \\
20,001 and above & 12 & 6.0 \\
& Fisherman & 5 & 2.5 \\
& Vendor & 26 & 13.0 \\
& Sari-sari store owner & 7 & 3.5 \\
& Washerwoman & 3 & 1.5 \\
& Farmer & 14 & 7.0 \\
& Employee/businessman/professional & 43 & 21.5 \\
& Housewife & 102 & 51.0 \\
Other sources of income & Buy and sell/sari-sari store & 65 & 32.5 \\
& Farming/farm laborer/fishing & 31 & 15.5 \\
& Business owner/Manager & 26 & 13.0 \\
& Salary from relatives & 6 & 3.0 \\
& None & 72 & 36.0 \\
\hline
\end{tabular}

In the study cited from Diaz and Ledesma (2011), the sources of income of microfinance clients are the common jobs being held by spouses like working as security guard, factory workers, construction worker, company or family driver and government employee. Among the services provided by spouses are tricycle driving and carpentry, while some spouses are also farmers and fisherman. In general, loans will be paid from these income sources.

\subsection{Driving forces of household-clients in availing microfinance services}

Table 3 shows the driving forces of microfinance household clients in availing the services. It shows that financial security $(76 \%)$ is the most common driving force of microfinance household clients, followed by health- related concerns $(72.50 \%)$. Majority $(69 \%)$ of the driving forces of the clients is related with education, while $26 \%$ is driver by engagement in microenterprises, such as operating a sari-sari store. Some (19\%) availed microfinance services for agricultural purposes, particularly to acquire capital for those clients with farm lands. Based on the result, microfinance services offer varied purposes for the household clients - from short-term utilization such as for education and health-related concerns to long-term uses such as capital for farming activities and establishment of microenterprises.

Table 3. Driving Forces of Household-clients in Availing Microfinance Services.

\begin{tabular}{lcc}
\hline \multicolumn{1}{c}{ Driving Forces* } & Frequency & Percentage (\%) \\
\hline Health-related concerns & 145 & 72.50 \\
Financial security & 152 & 76.00 \\
Education & 138 & 69.00 \\
Agricultural purposes & 38 & 19.00 \\
Microenterprises & 52 & 26.00 \\
\hline
\end{tabular}

* multiple response 
This study is supported by Diaz and Ledesma (2011) that most common reason cited for borrowing from MFI is the presence of a broad range of products to meet the varying needs of the clients. This product includes loan, savings and insurance. Microfinance household clients availed these products because it helps them become progressive, like insurance and savings that one can grow and monitor. In addition of products to avail such as housing loan when one can show good repayment record. Clients identified loan payment as a major household expense and accords it third priority - coming after food and school allowance of children. Food is given highest priority as a healthy body enables them to work and earn. Clients also view education as an investment with the expressed hope that when the children graduate, they could earn and contribute to the family income.

\section{Microfinance household clients frequently availed services}

Table 4.1 shows the MFIs that cater the need of the household clients. It shows that many (90.5\%) are availing the services of Center for Agriculture and Rural Development Bank Incorporated (CARD Bank). Small number of clients interviewed availed from Agricultural Development for Catanduanes Inc. (ARDCI) (7\%), Life Bank Microfinance Foundation Inc., Sim Microfinace Services Inc. (6\%), ASA Foundation Inc. (6\%) and Taytay sa Kauswagan Inc. (1.5\%). The said microfinance institutions offered services: loans and they required their clients to avail savings and insurance/micro insurance. Most of the interviewed microfinance clients are members of CARD Bank, since it is a basic requirement to apply for membership first before accessing or availing their services.

Table 4.1. Microfinance institutions serving household clients.

\begin{tabular}{lcc}
\hline \multicolumn{1}{c}{ Microfinance Institutions (MFIs)* } & Frequency & Percentage (\%) \\
\hline $\begin{array}{l}\text { Center for Agriculture and Rural Development } \\
\text { Bank Incorporated (CARD Bank) }\end{array}$ & 181 & 90.5 \\
Taytay sa Kauswagan Inc. & 3 & 1.5 \\
Agricultural Development for Catanduanes & 14 & 7.0 \\
Inc. (ARDCI) & & \\
& 12 & 6.0 \\
Sim Microfinace Services Inc. & 12 & 6.0 \\
ASA Foundation Inc. & 3 & 1.5 \\
Life Bank Microfinance Foundation Inc. & & \\
\hline
\end{tabular}

* multiple response

Table 4.2 shows the microfinance household clients' availed/accessed/paid services. All of the respondents availed savings because MFI required their clients to have savings. Other most availed services are insurance $(90.5 \%)$ and loans $(80 \%)$. Sikap loan is the first offered services to the first member of the MFI, specifically CARD Bank. Other significant services/kinds of loan availed at least once a year are additional loan, cell phone loan, housing loan, etc. But granting of those services depended on the repayment record of the borrower/client. Diaz \& Ledesma (2011) mentioned that in additional loan, some microfinance clients avail other services such as housing loan when one can show good repayment record. One may need a loan; others need more than one loan, while there is another group who may need to borrow and would rather have access to micro insurance and savings.

Table 4.2. Distribution of microfinance household clients based on availed/accessed/paid services.

\begin{tabular}{lcc}
\hline \multicolumn{1}{c}{ Availed/Accessed/Paid Services* } & Frequency & Percentage (\%) \\
\hline Savings & 200 & 100.0 \\
Insurance & 181 & 90.5 \\
Loans & 160 & 80.0 \\
Others/kinds of loans & 44 & 22.0 \\
\hline * multiple response & &
\end{tabular}


Table 4.3 shows the distribution of microfinance household clients based on their frequently availed/accessed/paid services. Because of the good repayment record of the microfinance household clients, $16.5 \%$ were able to avail once a year other kinds of loan like cell phone loan, additional loan, educational loan and housing loan. The $41 \%$ of the microfinance household clients was availed loan once a year. These services were availed of microfinance household clients according their ability to pay. All of the clients are saving weekly. This is being encouraged by MFIs. According to the interview conducted with the clients, they are trying their best to fulfill this responsibility, because this is also their source of funds when they have shortage in income for their household expenses.

Table 4.3. Distribution of microfinance household clients based on their frequently availed/accessed/paid services.

\begin{tabular}{lccc}
\hline \multicolumn{1}{c}{$\begin{array}{c}\text { Availed/Accessed/Paid } \\
\text { services* }\end{array}$} & Period & Frequency & Age (\%) \\
\hline Savings & Weekly & 200 & 100.0 \\
& Weekly & 173 & 86.5 \\
Insurance & Monthly & 2 & 1.0 \\
& Yearly & 5 & 5.0 \\
& Seasonal & 1 & 1.0 \\
Loans & Once a year & 82 & 41.0 \\
& Twice a year & 74 & 32.0 \\
& Thrice a year & 4 & 2.0 \\
Other Services/kinds of loan & Once a year & 33 & 16.5 \\
& Twice a year & 8 & 4.0 \\
& Thrice a year & 2 & 1.0 \\
& Seasonal & 1 & 1.0 \\
\hline
\end{tabular}

*multiple response

\section{Perceived effect of microfinance services}

Table 5 shows the effect of microfinance services in economic, social and personal aspects of household clients. In terms of economic aspect, majority (91\%) of the respondents experienced reduced poverty through microfinance institution, while $79 \%$ had increased their savings. Seventyseven (77) percent had increased their acquired assets such as appliances, machineries, gadgets, motorcycle, etc. Some of the respondents established enterprise through microfinance like ukay-ukay, sari-sari store, business expansion, carinderia and piggery for business. It shows that microfinance household clients were able to manage the granted services offered by the MFIs to improved their economic life. By the services availed of microfinace household clients, they promote productive behavior and foster income-generating activities to reduce poverty in daily lives.

Table 5. Perceived effect of microfinance services.

\begin{tabular}{llcc}
\hline \multicolumn{1}{c}{ Perceived effect* } & Frequency & Percentage (\%) \\
\hline \multirow{5}{*}{ Economic } & 141 & 70.5 \\
& Increased income & 182 & 91.0 \\
& Reduced poverty & 154 & 77.0 \\
& Increased acquired assets & 48 & 24.0 \\
& Established enterprise & 74 & 37.0 \\
& Increased productivity & 158 & 79.0 \\
& Increased savings & 75 & 37.5 \\
& Increased capital & 123 & 61.5 \\
& Improved household management & 180 & 90.0 \\
\multirow{5}{*}{ Personal } & Improved lifestyle & 195 & 97.5 \\
& Improved public relations/relationships with other people & 189 & 94.5 \\
& Increased self-confidence and fullfilment & 100 & 50.0 \\
& Improved educational level & 152 & 76.0 \\
\hline
\end{tabular}

*multiple response 
In terms of social aspect, the factor with the highest percentage of $97.5 \%$ or with equivalent of 195 household clients out of 200 respondents had improved public relations/relationship with other people. Through microfinance, household clients improved their social life. Some MFIs require meeting every week, and this means meeting with fellow clients and socialization. Also, because of improved income, clients, along with their family members were able to have improved lifestyle $(90 \%)$.

As for the personal aspect of the clients, $94.5 \%$ of the respondents said they had increased selfconfidence and fulfillment, while $76 \%$ had increased involvement in family's decision making. Being able to provide financially for the family is a very important matter, most especially to poor families, who have meager income. Through the MFIs, they were able to have increased income because of different livelihood that they were able to establish such as sari-sari, ukay-ukay, carinderia, etc.

\section{Conclusions}

Most of the respondents are female, married and literate. They have other sources of income; Among the most common driving forces of household clients in availing microfinance services are financial security, health-related concerns and education; The frequently availed services of household clients are savings, insurance and loans and their most common microfinance service provider is Center for Agriculture and Rural Development Incorporated (CARD Bank); The household clients experienced reduced poverty and increased acquisition of assets as economic effect of microfinance services, while they had improved lifestyle and improved relationships with other people as social effects and increased self-confidence and fulfillment as personal effects of microfinance services.

\section{Acknowledgments}

The author would like to thank microfinance clients of San Jose, Occidental Mindoro, as well as microfinance providers.

\section{References}

Asian Development Bank. (2007). Effects of Microfinance on Poor Rural Households and Status of Women. Retrieved August 12, 2018, from https:/www.adb.org/documents/

Bangko Sentral ng Pilipinas. (u.d.). Facts regarding Microfinance. Retrieved March 19, 2019, from http://www.bsp.gov.ph/about/advocacies_micro_facts.asp

Bersales, L. G. (2016). Average Estimated Income in 2015 is Estimated at 22 Thousand Pesos Monthly (Result from 2015 Family Income and Expindetures Survey). Philippine Statistics Authority. Retrieved February 24, 2018, from https://www.psa.gov.ph/content/averagefamily-income-2015

Diaz, J., \& Ledesma, J. M. (2011). Over-Indebtedness in the Philippines: Clients' Perceptions . Retrieved October 27, 2017, from http://www.microsave.net/files/pdf/Over_indebtedness_In_The_Philippines_Clients_Perception s.pdf

Geron, D. (2010). Microfinance Industry Report Philippines. Microfinance Council of the Philippines, Inc. Retrieved October 26, 2017, from http://www.microfinancecouncil.org/wpcontent/uploads/2011/12/MCPI_Microfinance-Industry-Report_2010.pdf

Habaradas, D. B., \& Umali, M. (2013). The Microfinance Industry in the Philippines: Striving for Financial Inclusion in the Midst of Growth. Retrieved September 10, 2017, from http://www.dlsu.edu.ph/research/centers/cberd/pdf/microfinance-in-the-philippines-habaradasumali-final-2013.pdf 
Kondo, T., Orbeta, A. J., Dingcong, C., \& Infantado, C. (2008). Impact of Microfinace on Rural Households in the Philippines. Philippine Institute for Developmnet Studies. Retrieved November 26, 2017, from http://onlinelibrary.wiley.com/doi/10.111/j.1759-5436.2008

Muntengezawa, M., Gombarume, F. B., Njanike, K., \& Charikinya, A. (2011). The Impact of Microfinancing Institution on the Socio Economic Live of People in Zimbabue. Retrieved August 25, 2017, from http://upet.ro/annals/economics/pdf/2011/Mutengezanwa-GombarumeNjanike.pdf

Philippine Development Plan 2011-2016. Philippine Statistics Authority. (2015). Total Population, Households Population, and Number of Hosueholds by Province, City, Municipality, and Barangay San Jose, Occidental Mindoro.

Roman, P. B. (2004). Microfinance in the Banking Sector: Current Environment and Future Decisions. Paper presented during the $9^{\text {th }}$ National Convention on Statistics (NCS).

Suansing, B. (09 August 2017). Philippines' Poverty Rate: Rural Communities Still Left Behind. The Borgen Project. Retrieved January 15, 2018, from https://borgenproject.org/philippinespoverty-rate/

United Nations - Department of Economic and Social Affairs - Population Division. (2017). Household Size and Composition Around the World 2017 Data Booklet. Retrieved March 15, 2019, from http://www.un.org/en/development/d

Valdemar, D. C., Encinas, R. A., \& Imperio, M. D. (October 2007). Microfinance Activity in the Philippines. International Development Law Organization. Retrieved October 15, 2017, from https://www.microfinancegateway.org/sites/default/files/mfg-en-paper-microfinance-activityin-philippines-operational-and-regulatory-challenges-of-the-microfinance-industry-in-thephilippines-oct-2007_1.pdf 